OPEN ACCESS

Edited by:

Manoj Kumar,

University of Technology Sydney,

Australia

Reviewed by:

Mangal Singh Rathore,

Council of Scientific and Industrial

Research (CSIR), India

Janice McCauley,

University of Technology Sydney,

Australia

*Correspondence:

Pannaga P. Jutur

jppavan@icgeb.res.in

Specialty section:

This article was submitted to

Aquatic Physiology,

a section of the journal

Frontiers in Marine Science

Received: 24 June 2020

Accepted: 07 September 2020

Published: 06 October 2020

Citation:

Singh R, Paliwal C, Nesamma AA, Narula $A$ and Jutur PP (2020) Nutrient Deprivation Mobilizes the Production

of Unique Tocopherols as

a Stress-Promoting Response in a

New Indigenous Isolate

Monoraphidium sp.

Front. Mar. Sci. 7:575817.

doi: 10.3389/fmars.2020.575817

\section{Nutrient Deprivation Mobilizes the Production of Unique Tocopherols as a Stress-Promoting Response in a New Indigenous Isolate Monoraphidium sp.}

\author{
Rabinder Singh ${ }^{1,2}$, Chetan Paliwal ${ }^{1}$, Asha A. Nesamma ${ }^{1}$, Alka Narula ${ }^{2}$ and \\ Pannaga $P$. Jutur ${ }^{1 *}$
}

' Omics of Algae Group, Industrial Biotechnology, International Centre for Genetic Engineering and Biotechnology, New Delhi, India, ${ }^{2}$ Department of Biotechnology, School of Chemical and Life Sciences, Jamia Hamdard University, New Delhi, India

The economic feasibility of the next-generation algal biofuels rely largely on the simultaneous production of high-value-added bioproducts (HVABs) in these photosynthetic cell factories. In this study, a newly isolated indigenous microalga belonging to the selenastraceae family Monoraphidium sp. (designated as CABeR41) has been isolated and characterized for its relevant biofuel precursors along with other HVABs, i.e., tocopherols. Our preliminary data sets demonstrate accumulation of higher amounts of lipids (266.6 $\mathrm{mg} \mathrm{g}^{-1} \mathrm{dcw}$ ) along with antioxidant molecules, such as $\alpha$ and $\delta$-tocopherols (456 $\mu \mathrm{g} \mathrm{g}^{-1} \mathrm{dcw}$ and $974 \mu \mathrm{g} \mathrm{g}^{-1} \mathrm{dcw}$ ), simultaneously when subjected to nutrient deprivation. The total tocopherol content has been increased in nitrogen-deplete conditions to $1450.24 \mu \mathrm{g} \mathrm{g}^{-1} \mathrm{dcw}$ from $638.2 \mu \mathrm{g} \mathrm{g}^{-1} \mathrm{dcw}$. In conclusion, bioprospecting of new isolates from natural habitats and fine-tuning of specific conditions without compromising growth has potential for developing into a sustainable industrial strain for concomitant production of biofuels and bioproducts.

Keywords: Monoraphidium, nutrient deprivation, tocopherols, microalgae, environmental stress

\section{INTRODUCTION}

Global population demands and rapid industrialization have led to remarkably high consumption of natural petroleum, creating urgency to look for alternative, renewable sources (Gao et al., 2019). Microalgae are photosynthetic microorganisms fixing $~ 9 \%$ of solar energy to generate biomass efficiently compared to terrestrial plants, sequestering $\sim 513$ tons ha ${ }^{-1}$ year ${ }^{-1}$ of atmospheric $\mathrm{CO}_{2}$ without competing for arable land with food crops (Chen et al., 2018). Microalgae are sustainable and potential feedstock for biofuels and other high-value-added bioproducts (HVABs), such as carotenoids, polyunsaturated fatty acids (PUFAs), and vitamins (Durmaz, 2007; Borowitzka, 2013; Skjånes et al., 2013; Paliwal et al., 2016). The primary barrier for commercialization of algal-derived biofuels is presumably the production costs. Henceforth, the concurrent processing of co-products from microalgae would be offset for the production of biofuels (Stephens et al., 2010; Wijffels and Barbosa, 2010). Strategies for the accumulation of lipids and carotenoids can be triggered by stress 
conditions, such as nutrient deprivation and/or other external factors (Sun et al., 2018).

Macronutrients, such as carbon, nitrogen, and phosphorous along with other micronutrients (mainly comprising iron, manganese, and zinc), play an important role in microalgal growth. The effect of such nutrients are well documented in strains such as Chlorella sorokiniana, Chlorella vulgaris, Dunaliella tertiolecta, and Tetraselmis suecica (Ghafari et al., 2018). Nitrogen, for example, is a key element of cellular biomolecules, including DNA, protein, and chlorophyll, which affects growth and other biosynthetic pathways (Simionato et al., 2013). Previous studies on nitrogen deprivation demonstrate the accumulation of reactive oxygen species (ROS), such as $\mathrm{H}_{2} \mathrm{O}_{2}$, superoxide $\left(\mathrm{O}_{2}{ }^{-}\right)$, and hydroxyl $(\mathrm{OH})$ radicals that lead to growth hampering, reduced protein, and chlorophyll synthesis preceded by concomitant increase in the lipid and/or carbohydrate contents (Pérez-Pérez et al., 2012). ROS molecules are mainly involved in cellular signaling processes, but excess production may lead to apoptosis. In order to control and mitigate stress, the cell produces biomolecules, such as tocopherols, polyphenols, carotenoids, flavonoids, and other enzyme scavengers, like superoxide dismutase (SOD), catalase, and ascorbate peroxidase (APX), as an integral part of the internal defense mechanism (Cirulis et al., 2013).

Tocopherols are possibly regarded as efficient microalgal HVABs that defend fatty acids against the oxidation process and ensure the stability of the lipid membrane (Fritsche et al., 2012; Lv et al., 2015). $\alpha$-tocopherol has the greatest antioxidant potential and is one of the leading tocopherols present in both algae and plants (Mudimu et al., 2017). Biosynthesis of tocopherol exists in chloroplasts, and because human beings cannot synthesize it, it is provided as a dietary supplement (Munné-Bosch and Alegre, 2002). These tocopherols can prevent and inhibit oxidative damage and, hence, are used as cardioprotective additives as well as UVprotectants and antiaging creams in cosmetics (Poljšak and Fink, 2014). A study indicates the existence of another type of tocopherol, i.e., $\delta$-tocopherol, with unique antioxidant and anti-inflammatory properties (Ahsan et al., 2014). However, a number of algal strains, such as Nannochloropsis oculata (1.4 $\left.\mathrm{mg} \mathrm{g}^{-1}\right)$, Haematococcus pluvialis $\left(0.8 \mathrm{mg} \mathrm{g}^{-1}\right)$, Euglena gracilis (2.6 $\left.\mathrm{mg} \mathrm{g}^{-1}\right)$, and Coccomyxa sp. (0.42 $\left.\mathrm{mg} \mathrm{g}^{-1}\right)$ were identified as potential $\alpha$-tocopherol producers (Ogbonna et al., 1998; Durmaz, 2007; Mudimu et al., 2017).

In the present study, our focus is to identify and optimize the strain for the production of biofuels and HVABs simultaneously; thus, it could be categorized as an efficient strain for sustainable algal biorefinery. The stress-promoting responses on newly isolated indigenous microalga Monoraphidium sp. was studied for understanding their physiology and regulation of carbon flux into major metabolic pathways, such as lipid, carbohydrate, and protein biosynthesis when subjected to nutrient deprivation. We further evaluate the impact of the stress phenomenon on photosynthetic activity and also characterized few HVABs, such as tocopherols, to understand their role in oxidative damage within these microalgal cells.

\section{MATERIALS AND METHODS}

\section{Isolation of Strain(s)}

Microalgae was isolated from freshwater springs near the Dharamshala $\left(32^{\circ} 14^{\prime} 40.1^{\prime \prime} \mathrm{N} 76^{\circ} 20^{\prime} 03.2^{\prime \prime} \mathrm{E}\right)$ in the Kangra district of Himachal Pradesh, India. Samples $(2 \mathrm{~mL})$ collected from the springs were inoculated in BG-11 medium (50 mL) initially and grown for 14 days following 16:8 light/dark periods under light intensity $\left(80 \mu \mathrm{E} \mathrm{m} \mathrm{m}^{-2} \mathrm{~s}^{-1}\right)$ and temperature of $25^{\circ} \mathrm{C}$ with constant shaking at $150 \mathrm{rpm}$. Isolation of axenic cultures was carried out by serial dilution followed by the spread-plate technique until unialgal colonies were obtained (Lee et al., 2014) and the isolated stock cultures were maintained on agar slants for further experiments.

\section{Molecular Characterization of Newly Isolated Indigenous Strain}

The unialgal/axenic culture was maintained in Erlenmeyer flasks $(50 \mathrm{~mL})$ containing minimal medium (BG-11) at $80 \mu \mathrm{E} \mathrm{m}^{-2} \mathrm{~s}^{-1}$ light intensity, $16: 8 \mathrm{~h}$ light/dark photoperiods and $25^{\circ} \mathrm{C}$ at $150 \mathrm{rpm}$. Genomic DNA was extracted from the cells $\left(\sim 10^{9}\right.$ cells) in the logarithmic phase using the Zymo Research kit (Quick-DNA Fungal/Bacterial Microprep Kit, Catalog No. D6007, United States) as per the manufacturer's instructions. The DNA amplification was carried out with Internal Transcribed Spacer (Fritsche et al., 2012) region primers as follows: forward (5'-GGACAGAAAGACCCTATGAA-3') and reverse (5'-TCAGCCTGTTATCCCTAGAG-3'). The polymerase chain reaction (PCR) performed in the BioRad $\mathrm{T} 100^{\mathrm{TM}}$ Thermal Cycler using the program: preheating at $95^{\circ} \mathrm{C}$ for $3 \mathrm{~min}$ followed by 35 cycles of denaturation for $1 \mathrm{~min}$ at $95^{\circ} \mathrm{C}$, annealing at $58^{\circ} \mathrm{C}$ for $1 \mathrm{~min}$, and extension at $72^{\circ} \mathrm{C}$ for $90 \mathrm{~min}$ followed by another $10 \mathrm{~min}$ extension at $72^{\circ} \mathrm{C}$. Later, the PCR products were visualized by electrophoretic separation on $1.5 \%$ agarose gels and sequenced. The ITS rRNA sequences were searched for homology in the NCBI database employing nucleotide BLAST $^{1}$. All the retrieved sequences were aligned by multiple sequence comparison by log-expectation (MUSCLE) alignment (Edgar, 2004) followed by phylogenetic analysis using molecular evolutionary genetics analysis (Hall, 2013; Lee et al., 2014) employing the neighbor joining method with 1000 rounds of bootstrapping (Saitou and Nei, 1987). The sequence is deposited to the GenBank with accession no. MT622543.

\section{Culture Conditions}

A total number of cells $\left(\sim 10^{8}\right)$ were inoculated at a logarithmic phase containing $1.5 \mathrm{~g} \mathrm{~L}^{-1}$ of $\mathrm{NaNO}_{3}$ (termed nitrogen replete) and $0 \mathrm{~g} \mathrm{~L}^{-1}$ of $\mathrm{NaNO}_{3}$ (nitrogen deplete) in BG-11 medium, respectively, i.e., approximately $0.056 \mathrm{~g} \mathrm{~L}^{-1} \mathrm{DCW}$ biomass with an initial optical density $\left(\mathrm{OD}_{750}\right)$ of 0.1 . The cells were grown in BG-11 medium for 10 days at $25^{\circ} \mathrm{C}$ in $16: 8 \mathrm{~h}$ light/dark photoperiods and a light intensity of $150 \mu \mathrm{E} \mathrm{m} \mathrm{m}^{-2} \mathrm{~s}^{-1}$ with constant shaking at $150 \mathrm{rpm}$. Sampling was carried out at regular time intervals of $0,2,4,6,8$, and 10 days.

\footnotetext{
${ }^{1}$ http://blast.ncbi.nlm.nih.gov
} 
The cell growth was calculated using following equation (Kareya et al., 2020):

$$
\mu=\ln \left(N_{2} / N_{1}\right) /\left(t_{2}-t_{1}\right)
$$

where $\mu$ is the specific growth rate and $N_{1}$ and $N_{2}$ are the biomass at times $\left(t_{1}\right.$ and $\left.t_{2}\right)$, respectively. Doubling time was also calculated by the following equation:

$$
\text { Doubling time }=\ln (2) / \mu
$$

\section{Biochemical Characterization}

Lipid estimation was done by the sulfophosphovanillin assay (Mishra et al., 2014). Briefly, $1 \mathrm{~mL}$ of culture was pelleted down into $100 \mu \mathrm{L}$ of distilled water. Then, $2 \mathrm{~mL}$ of $98 \% \mathrm{H}_{2} \mathrm{SO}_{4}$ was added to cells and incubated at $100^{\circ} \mathrm{C}$ for $10 \mathrm{~min}$. After cooling for $5 \mathrm{~min}$ in ice, $5 \mathrm{~mL}$ of phosphovanillin reagent $(0.6 \mathrm{~g}$ vanillin in $10 \mathrm{~mL}$ of ethanol in $90 \mathrm{~mL}$ distilled water and $400 \mathrm{~mL} 85 \%$ phosphoric acid) were added, and the samples were incubated for $10 \mathrm{~min}$ at $37^{\circ} \mathrm{C}$, absorbance measured at $530 \mathrm{~nm}$.

A modified phenol-sulfuric acid method was used for total carbohydrate estimation (Paliwal et al., 2015). Then, $0.2 \mathrm{~mL}$ of $98 \% \mathrm{H}_{2} \mathrm{SO}_{4}$ was added to $100 \mu \mathrm{L}$ of cells and hydrolyzed at room temperature for $1 \mathrm{~h}$; subsequently, $5 \%$ phenol with $1 \mathrm{~mL}$ of $\mathrm{H}_{2} \mathrm{SO}_{4}$ was added and incubated at room temperature for $20 \mathrm{~min}$ after vortexing. The absorbance was measured at $490 \mathrm{~nm}$.

A modified biuret method used for quantification of protein content. Approximately $1 \mathrm{~mL}$ of cell suspension was pelleted down and $1 \mathrm{ml}$ of extraction buffer $(25 \% \mathrm{NaOH}$ in methanol) added. The reaction mixture was incubated for $15 \mathrm{~min}$ at $80^{\circ} \mathrm{C}$. The sample was cooled to room temperature and centrifuged to remove debris. Then, $300 \mu \mathrm{L}$ of the supernatant was treated with $150 \mu \mathrm{L}$ of $\mathrm{CuSO}_{4}$ solution $\left(0.21 \% \mathrm{CuSO}_{4}\right.$ in $\left.30 \% \mathrm{NaOH}\right)$ and incubated at room temperature for $10 \mathrm{~min}$, and further absorbance was measured at $310 \mathrm{~nm}$.

\section{Nile Red Staining}

For visualization of triacylglycerols (TAGs) in microalgae, cells were stained with fluorescent lipid-sensitive Nile Red fluorescent dye (Janchot et al., 2019). A Nile Red concentration of $0.5 \mu \mathrm{g} \mathrm{mL} \mathrm{m}^{-1}$ in $25 \%$ of dimethyl sulfoxide (DMSO) was added to $1 \mathrm{~mL}$ of cell culture and stained for $20 \mathrm{~min}$ at $37^{\circ} \mathrm{C}$ (Cooksey et al., 1987). Lipid bodies were visualized by fluorescence microscopy, and images were captured through a Nikon 80i epifluorescence microscope (Nikon, Japan) equipped with a camera Q-Imaging Micropublisher 3.3 RTV (Real Time Viewing), and Image-Pro Plus v6.0 software (Media Cybernetics, Inc., Bethesda, MD, United States).

\section{Scanning Electron Microscopy}

Morphological changes in the Monoraphidium sp. CABeR41 when subjected to nutrient deprivation was captured by scanning electron microscopy (SEM). Samples were prepared by washing $\sim 10^{7}$ cells with $0.1 \mathrm{M}$ sodium phosphate buffer ( $\mathrm{pH} 7.2$ ). Later, the samples were fixed overnight with $2.5 \%$ of glutaraldehyde and incubated at $4^{\circ} \mathrm{C}$ for SEM analysis (Lambrecht et al., 2015).

\section{Estimation of Nitrate Utilization}

Nitrate uptake by the cells was carried out spectrophotometrically (Collos et al., 1999). Briefly, $1 \mathrm{~mL}$ of culture was pelleted down at room temperature, and supernatant was diluted 50 -fold with deionized water. The residual nitrate content was determined by measuring the absorbance at $220 \mathrm{~nm}$.

\section{PAM Measurements}

A dual-PAM100 fluorometer (Heinz Walz, Effeltrich, Germany) measured the fluorescence signals and microalgal cells were darkadapted for $30 \mathrm{~min}$ before measuring fluorescence. Maximum fluorescence $F_{m}$ was determined by directing a saturation pulse (6000 $\mu$ mol photons $\mathrm{m}^{-2} \mathrm{~s}^{-1} ; \lambda=660 \mathrm{~nm}$ ) and quantum efficiency of PS II calculated by $\left(F_{v} / F_{m}=\left(F_{m}-F_{o}\right) / F_{m}\right)$ (Agarwal et al., 2019). Further quantum yields of photochemical quenching Y, non-photochemical quenching Y (NPQ), and thermal energy dissipation in the form of heat and fluorescence occurring during closed PSII system Y (NO) was calculated from the fluorescence values obtained (Kareya et al., 2020).

\section{Fatty Acid Methyl Esters (FAME) Quantification by GC-MS}

Quantification of FAME was done by the method described previously (Shaikh et al., 2019). Briefly, $\sim 10^{8}$ cells were hydrolyzed and methyl trans-esterified at $80^{\circ} \mathrm{C}$ with $50 \mu \mathrm{g}$ heptadecanoic acid as an internal standard in $300 \mu \mathrm{l}$ of $2 \%$ $\mathrm{H}_{2} \mathrm{SO}_{4}$ and methanol solution for $2 \mathrm{~h}$. Then, $300 \mu \mathrm{l}$ of $0.9 \%$ $\mathrm{NaCl}$ and $300 \mu \mathrm{l}$ of hexane were added simultaneously after trans-esterification and mixed thoroughly for $20 \mathrm{~s}$. Centrifugation was done at $3000 \times g$ for $3 \mathrm{~min}$ and the clear upper hexane layer taken into vials. Then, $1 \mu \mathrm{l}$ of sample was injected into an Agilent 6890 gas chromatograph (GC) coupled to a mass spectrometer (MS) equipped with Omega Wax 250 column $(30 \mathrm{~m} \times 0.25 \mathrm{~mm} \times 0.25 \mu \mathrm{m})$. The FAME was detected by an electron ionization detector. The running conditions for GC-MS were described by Agilent's RTL DB Wax method.

\section{Quantification of Pigments and Tocopherols}

For pigment estimation, $1 \mathrm{~mL}$ of culture was centrifuged at $7500 \times g$ for $10 \mathrm{~min}$ at $4^{\circ} \mathrm{C}$. Pigment extraction was performed by adding $95 \%$ absolute ethanol and glass beads to the pellet followed by vortexing for $10 \mathrm{~min}$ at room temperature. The debris was pelleted down, and the supernatant was used for measuring absorbance at 648, 664, and $470 \mathrm{~nm}$. The concentration of Chlorophyll $\mathrm{a}\left(\mathrm{C}_{\mathrm{a}}\right)$, Chlorophyll $\mathrm{b}\left(\mathrm{C}_{\mathrm{b}}\right)$, and Carotenoids $(\mathrm{C})$ were calculated by using the following equation (Lichtenthaler and Buschmann, 2001):

$$
\begin{gathered}
\mathrm{C}_{\mathrm{a}}\left(\mu g m L^{-1}\right)=13.36 \mathrm{~A}_{664}-5.19 \mathrm{~A}_{648} \\
\mathrm{C}_{\mathrm{b}}\left(\mu g m \mathrm{~g}^{-1}\right)=27.43 \mathrm{~A}_{648}-8.12 \mathrm{~A}_{664} \\
\mathrm{C}\left(\mu g \mathrm{gm}^{-1}\right)=\left(1000 \mathrm{~A}_{470}-2.13 \mathrm{C}_{\mathrm{a}}-97.64 \mathrm{C}_{\mathrm{b}}\right) / 209
\end{gathered}
$$

Tocopherols were estimated by a previously described method (Moltó-Puigmartí et al., 2009) with slight modifications. Briefly, 
$\sim 10^{7}$ cells were centrifuged at $10,000 \times g$ for $10 \mathrm{~min}$, and $500 \mu \mathrm{L}$ of absolute ethanol and glass beads were used for extraction of tocopherols. The solution was vortexed for $10 \mathrm{~min}$ with 2 min intermittent ice bath incubation. For phase separation, $500 \mu \mathrm{L}$ of hexane and $200 \mu \mathrm{L}$ of distilled water were added after extraction followed by centrifugation $(2200 \times g)$ for $10 \mathrm{~min}$ at $4^{\circ} \mathrm{C}$. The upper hexane layer was collected and evaporated to dryness under a nitrogen stream. Finally, the dried extract was resuspended into $200 \mu \mathrm{L}$ of dichloromethane:methanol (2:1) and analyzed by an Agilent HPLC system (1260 Infinity II LC System, United States). Then, $10 \mu \mathrm{L}$ of samples were injected and eluted in isocratic mode through an Eclipse plus C18 column (95 ̊, $4.6 \times 150$ mm, $5 \mu \mathrm{m}$; Agilent Technologies, United States) using acetonitrile:methanol $(60: 40, \mathrm{v} / \mathrm{v})$ at a constant flow rate of $0.6 \mathrm{~mL} \mathrm{~min}^{-1}$. Tocopherols were detected using a fluorescence detector with an excitation/emission wavelength of 297/328 nm, respectively. Tocopherols were quantified based on peak area ratio using analytical standards.

\section{Statistical Analysis}

All the experiments were carried out in biological triplicate and the analysis of variance done by Fischer's least significant difference (LSD) (Meier, 2006; Di Rienzo et al., 2011). The values were represented as average \pm standard error (SE) and the statistical differences were calculated at $p<0.05$.

\section{RESULTS}

\section{Identification of New Isolate (Microalgae) From Natural Environments}

With the growing world population and increasing demand for high-quality nutritional supplements, new microalgae strains need to be explored from various natural environments providing a promising resource for HVABs in the near future. The indigenous strain isolated from Dharamshala (India) was morphologically identical to the Selenestraceae family with spindle shape and tapering toward apices. It is not possible to determine the identity of the strain by morphology alone due to the vast diversity existing among algal strains. Therefore, ITS rRNA sequencing was performed to identify the strain, and the obtained sequence was submitted to the NCBI GenBank with accession number (MT622543). The phylogenetic analysis of the ITS rRNA sequence showed close proximity with Monoraphidium contortum with a resemblance of $86.5 \%$ (Figure 1) and, hence, termed Monoraphidium sp. ${ }^{\#}$ CABeR41 (" local strain identifier).

\section{Growth Profiles and Biochemical Changes Under Nitrogen Deprivation}

At optimal conditions, with an initial inoculum of $\sim 10^{6}$ cells $\mathrm{mL}^{-1}$, the Monoraphidium sp. CABeR41 achieved a biomass of $0.682 \mathrm{~g} \mathrm{~L}^{-1}$ within 10 days, presenting better growth with a specific growth rate $0.20 \mathrm{~d}^{-1}$ and doubling time of $78.0 \mathrm{~h}$ (Figure 2A). An adequate supply of macronutrients along with other micronutrients play a crucial role in the growth of these

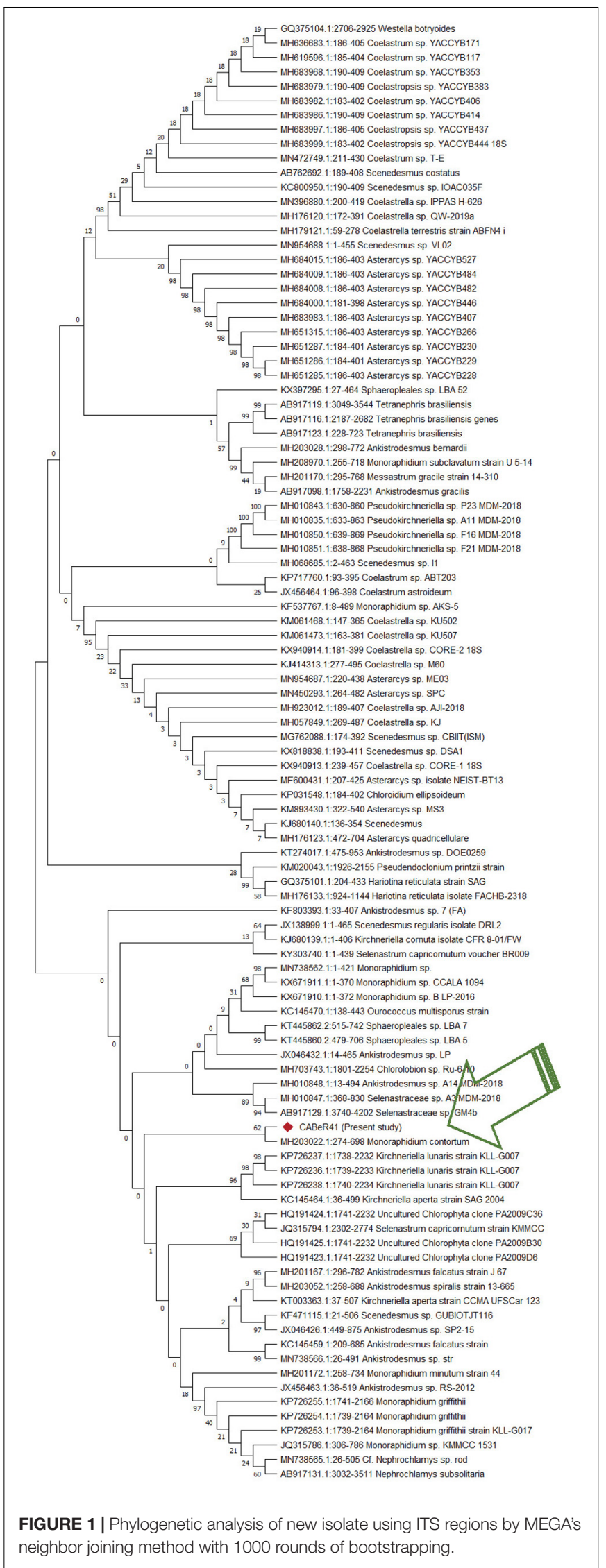




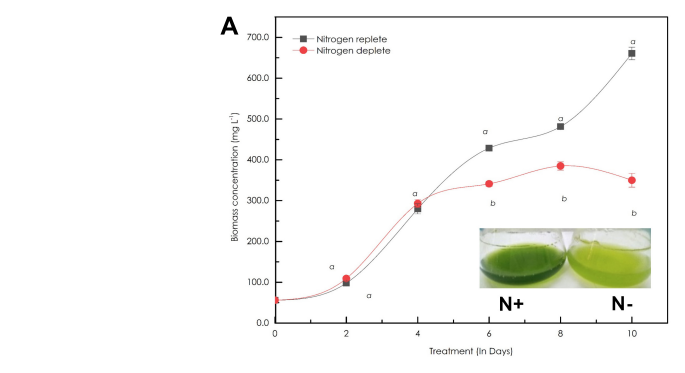

C

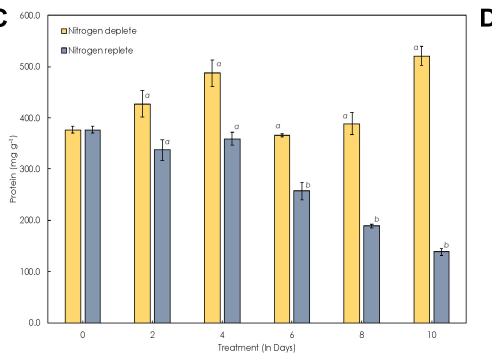

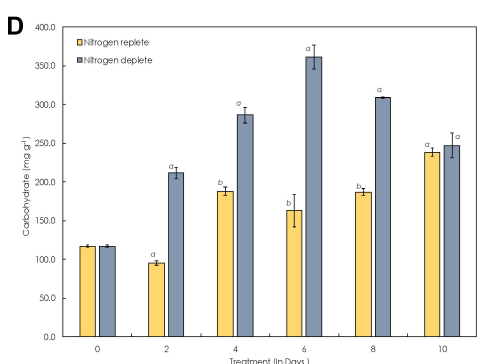

FIGURE 2 | Growth and biochemical profiles of Monoraphidium sp. CABeR41 under nitrogen replete and deplete conditions. (A) Growth curve; (B) nitrate utilization; (C) proteins; (D) carbohydrates; and (E) lipids. Statistical analysis was performed using one-way ANOVA with Fisher's LSD test, and significance was determined if $p<0.05$. $a$ and $b$ both denotes the significant difference between the two conditions ( $a$, maximum; $b$, minimum).

TABLE 1 | Biochemical yields and productivity in replete and deplete conditions of Monoraphidium sp. CABeR41 on 10th day of cultivation.

\begin{tabular}{lcc}
\hline Parameters & Nitrogen replete & Nitrogen deplete \\
\hline Biomass $\left(\mathrm{mg} \mathrm{L}^{-1}\right)$ & $647.5 \pm 6.19^{\mathrm{a}}$ & $350 \pm 3.28^{\mathrm{b}}$ \\
Biomass productivity $\left(\mathrm{mg} \mathrm{L}^{-1} \mathrm{~d}^{-1}\right)$ & $62.56 \pm 0.62$ & $29.31 \pm 0.31$ \\
Specific growth rate $\left(\mathrm{d}^{-1}\right)$ & $0.20 \pm 0.01$ & $0.11 \pm 0.03$ \\
Lipid $\left(\mathrm{mg} \mathrm{g}^{-1}\right)$ & $165.7 \pm 3.59^{\mathrm{b}}$ & $266.3 \pm 7.57^{\mathrm{a}}$ \\
Lipid $\left(\mathrm{mg} \mathrm{L}^{-1} \mathrm{~d}^{-1}\right)$ & $7.77 \pm 0.05$ & $5.87 \pm 0.06$ \\
Protein $\left(\mathrm{mg} \mathrm{g}^{-1}\right)$ & $520.7 \pm 10.86^{\mathrm{a}}$ & $138.4 \pm 4.08^{\mathrm{b}}$ \\
Protein $\left(\mathrm{mg} \mathrm{L}^{-1} \mathrm{~d}^{-1}\right)$ & $21.70 \pm 0.04$ & $0.33 \pm 0.02$ \\
Carbohydrate $\left(\mathrm{mg} \mathrm{g}^{-1}\right)$ & $238.3 \pm 5.54^{\mathrm{a}}$ & $247.2 \pm 15.95^{\mathrm{a}}$ \\
Carbohydrate $\left(\mathrm{mg} \mathrm{L}^{-1} \mathrm{~d}^{-1}\right)$ & $10.57 \pm 0.38$ & $4.78 \pm 0.26$ \\
Total chlorophyll $\left(\mathrm{mg} \mathrm{g}^{-1}\right)$ & $14.5 \pm 0.65^{\mathrm{a}}$ & $3.1 \pm 1.75^{\mathrm{b}}$ \\
Carotenoid $\left(\mathrm{mg} \mathrm{g}^{-1}\right)$ & $3.77 \pm 0.24^{\mathrm{a}}$ & $1.2 \pm 0.19^{\mathrm{b}}$
\end{tabular}

Statistical analysis was performed using one-way ANOVA with Fisher's LSD test, and significance was determined if $p<0.05$. $a$ and $b$ both denotes the significant difference between the two conditions ( $a$, maximum; $b$, minimum).

microalgae. When subjected to nitrogen starvation (Figure 2A), a severe effect on the growth was observed, as it starts retarding after the 4th day of cultivation and cells succumb on the 8th day, showing signs of early senescence. The biomass yield on 10th day of cultivation in nitrogen deplete medium was $0.35 \mathrm{~g} \mathrm{~L}^{-1}$ with a specific growth rate $9.1 \mathrm{~d}^{-1}$ and doubling time of $219.0 \mathrm{~h}$. In addition, we also estimated utilization of nitrate uptake for 10 days in these cells under replete conditions, and it seems to be approximately $0.38 \mathrm{~g} \mathrm{~L}^{-1}$ (Figure 2B).

The biochemical constituents of these photosynthetic cell factories were estimated to evaluate the changes occurring during nitrogen deplete (Table 1). Among these, the protein content rapidly decreased after the onset of stress from the 4 th day and was reduced from $358.8 \mathrm{mg} \mathrm{g}^{-1} \mathrm{dcw}$ to $138.3 \mathrm{mg} \mathrm{g}^{-1}$ dcw, i.e., decreased by nearly twofold. When cells are in stress, the overall protein content reduces and is catabolized to form precursor molecules. During replete conditions, there was increase in protein content until the 4th day of cultivation (486.9 $\mathrm{mg} \mathrm{g}^{-1} \mathrm{dcw}$ ), and a decline was observed after the 4th day until the 8 th day (Figure $2 \mathrm{C}$ ), which may be due to nutrient deficiency within the media but recovers to maximal on the 10 th day. For carbohydrates, the overall content declines initially from $117.3 \mathrm{mg} \mathrm{g}^{-1} \mathrm{dcw}$ to $96.1 \mathrm{mg} \mathrm{g}^{-1} \mathrm{dcw}$ on the 2 nd day (Figure 2D), but increases substantially from $187.1 \mathrm{mg} \mathrm{g}^{-1} \mathrm{dcw}$ to $238.5 \mathrm{mg} \mathrm{g}^{-1} \mathrm{dcw}$ until the 10 th day of cultivation. However, carbohydrate yield was increased in nitrogen-deplete conditions from $117.1 \mathrm{mg} \mathrm{g}^{-1} \mathrm{dcw}$ to $361.0 \mathrm{mg} \mathrm{g}^{-1} \mathrm{dcw}$ (by nearly 1.5fold) during the first 6 days and later started to decrease on the 8th and 10th days of cultivation. Similarly, the total lipids in the nitrogen deplete condition increased from $13.9 \mathrm{mg} \mathrm{g}^{-1} \mathrm{dcw}$ to $266.3 \mathrm{mg} \mathrm{g}^{-1} \mathrm{dcw}$ until the 10 th day of cultivation, i.e., increased by eightfold (Figure 2E), whereas in nitrogen replete (Figure 2E), the lipid content was increased to $83.3 \mathrm{mg} \mathrm{g}^{-1}$ $\mathrm{dcw}$ from $14.0 \mathrm{mg} \mathrm{g}^{-1} \mathrm{dcw}$ by the 4 th day followed by increase up to $165.7 \mathrm{mg} \mathrm{g}^{-1} \mathrm{dcw}$ by the 10 th day. This phenomenon was also confirmed by fluorescence staining using NR uniform under both nutrient-replete and -deplete conditions in which a significant amount of lipid bodies was observed in deplete conditions (Figure 3).

\section{Microscopy Reveals Morphological Changes During Nitrogen Stress}

The light microscopy analysis of Monoraphidium sp. CABeR41 displayed that the shape of the cells remains intact without any 
change showing chloroplast density until the 8th day in nitrogenreplete conditions while the cells in the deplete state tend to be obese with significant changes in chloroplast structures. In starved conditions, morphological changes were observed after the 4th day itself, when cells became obese. Moreover, a massive change in chloroplast structures was observed after the 4 th day with a gradual decline in the chloroplast density. NR-stained fluorescent light imaging displayed that the yellowstained globules called lipid bodies were prominently visible at the 10th day in replete conditions, whereas the globules remain smaller in size. However, under nitrogen stress conditions, the cells start accumulating lipid droplets on the 4th day, whereas the cells tend to get obese gradually from day 6 (Figure 3). SEM images depict a rigid shaped structure with no disruptions in the nitrogen-replete condition, whereas in nitrogen depletion, the cells were showing the signs of the weakened cell wall structure (Figure 4).

\section{Changes in Photosynthetic Efficiency, Total Chlorophyll, and Carotenoid \\ Contents}

The total chlorophyll and carotenoid contents also followed a similar trend as observed in the growth profile of these cells. The total chlorophyll content in the control conditions almost doubled from $10.0 \mathrm{mg} \mathrm{g}^{-1} \mathrm{dcw}$ to $19.35 \mathrm{mg} \mathrm{g}^{-1}$

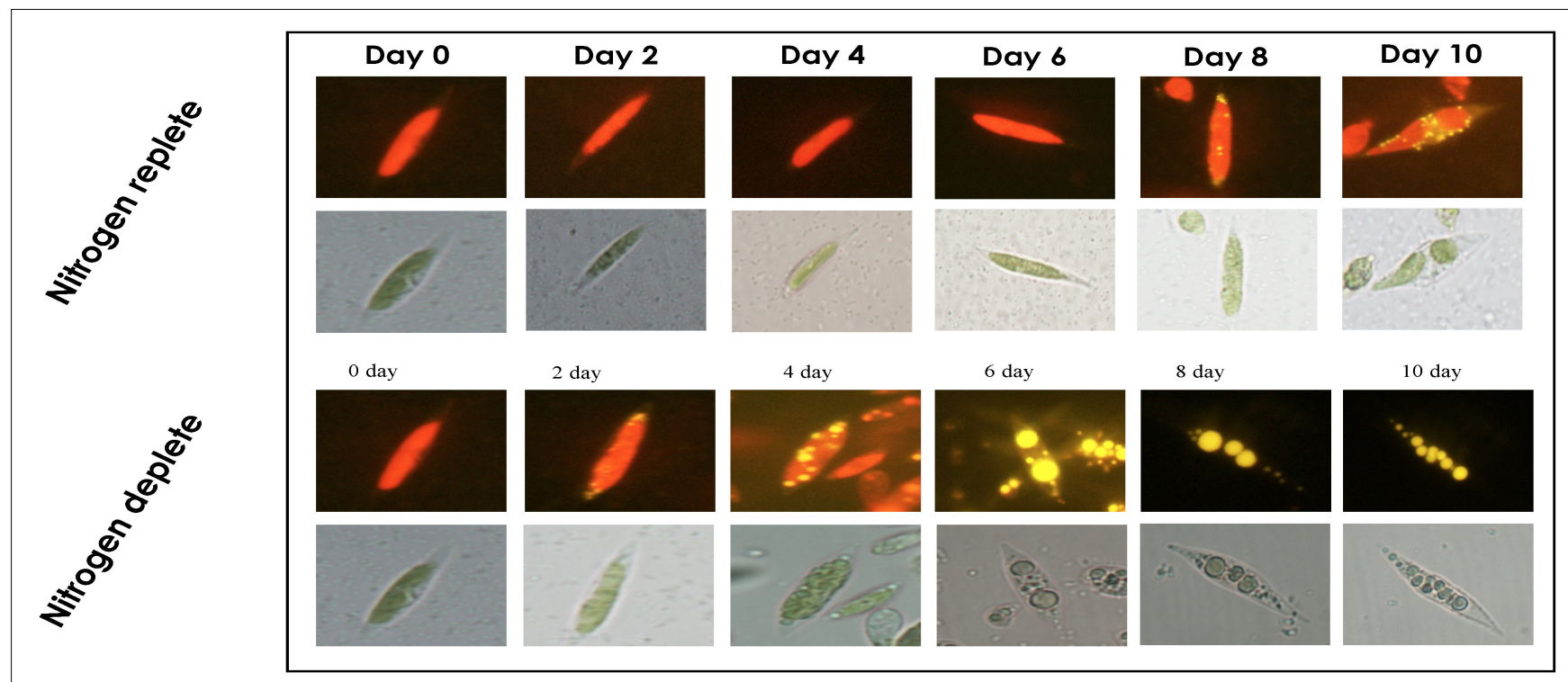

FIGURE 3 | Time-course analysis for visualizing lipid droplets in Monoraphidium sp. CABeR41 subjected to nitrogen replete and deplete conditions by Nile Red fluorescence microscopy.
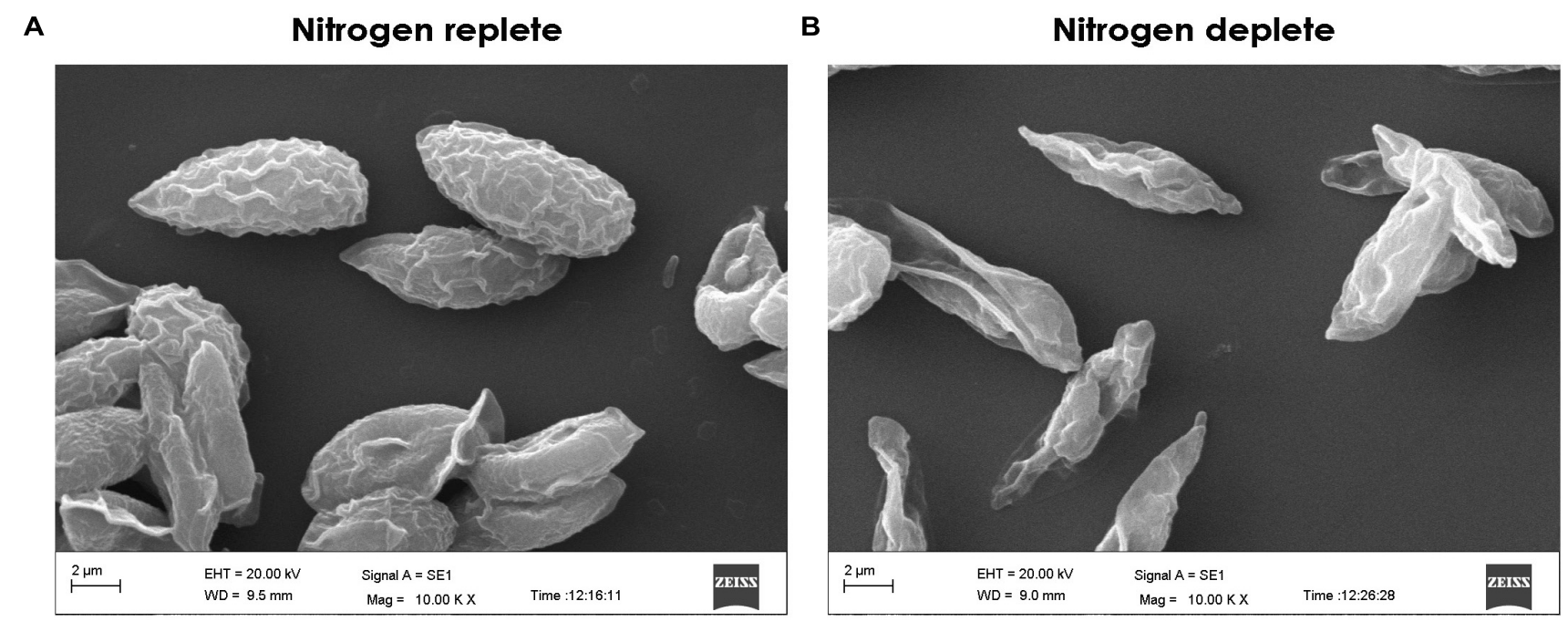

FIGURE 4 | Scanning electron microscopy (SEM) images of Monoraphidium sp. for (A) replete and (B) deplete conditions on the 10th day of cultivation. 
dcw in first 4 days: a $\sim 0.93$-fold increase. After the 4 th day, the chlorophyll content declined, yielding $15.38 \mathrm{mg} \mathrm{g}^{-1} \mathrm{dcw}$ on the 10th day (Figure 5A). In nitrogen starvation, the total chlorophyll content declined rapidly from $10.27 \mathrm{mg} \mathrm{g}^{-1}$ $\mathrm{dcw}$ to $0.63 \mathrm{mg} \mathrm{g}^{-1} \mathrm{dcw}$ on the 10th day, showing signs of reduced photosynthetic efficiency. Moreover, photosynthetic machinery, particularly in the case of nitrogen deficiency, is the major component affected during stress in these cell factories. Total carotenoid content in the replete condition increased from $1.0 \mathrm{mg} \mathrm{g}^{-1} \mathrm{dcw}$ to $7.90 \mathrm{mg} \mathrm{g}^{-1} \mathrm{dcw}$ by the 4th day and seems to have no change until the 10th day while in nitrogen-deplete cells they accumulate carotenoids until the 4th day up to $2.20 \mathrm{mg} \mathrm{g}^{-1} \mathrm{dcw}$ and later decline steadily to $0.90 \mathrm{mg} \mathrm{g}^{-1} \mathrm{dcw}$ by the 10th day (Figure 5B).
The maximum quantum efficiency of photosystem II $\left(F_{v} / F_{m}\right)$ in replete cells was 0.8 on the 2 nd day and increased simultaneously to remain constant at 0.84 on the 4th day of cultivation (Figure 6A), demonstrating that the cells are in a healthy state and the photosynthetic machinery of cells were highly active although a slight decrease in the $F_{v} / F_{m}$ was observed after the 4 th day even though it remained constant until the 10th day with an $F_{v} / F_{m}$ ratio of 0.68 . However, in the nitrogen stress-deplete condition, $F_{v} / F_{m}$ between the 4 th to the 10th day decreased from 0.61 to $0.24(40.38 \%)$ demonstrating that cells were in stress, and photosynthetic efficiency declined drastically. Moreover, the growth profile also correlates with this phenomenon showing a decrease from the 4th day onward in nitrogendeplete conditions.
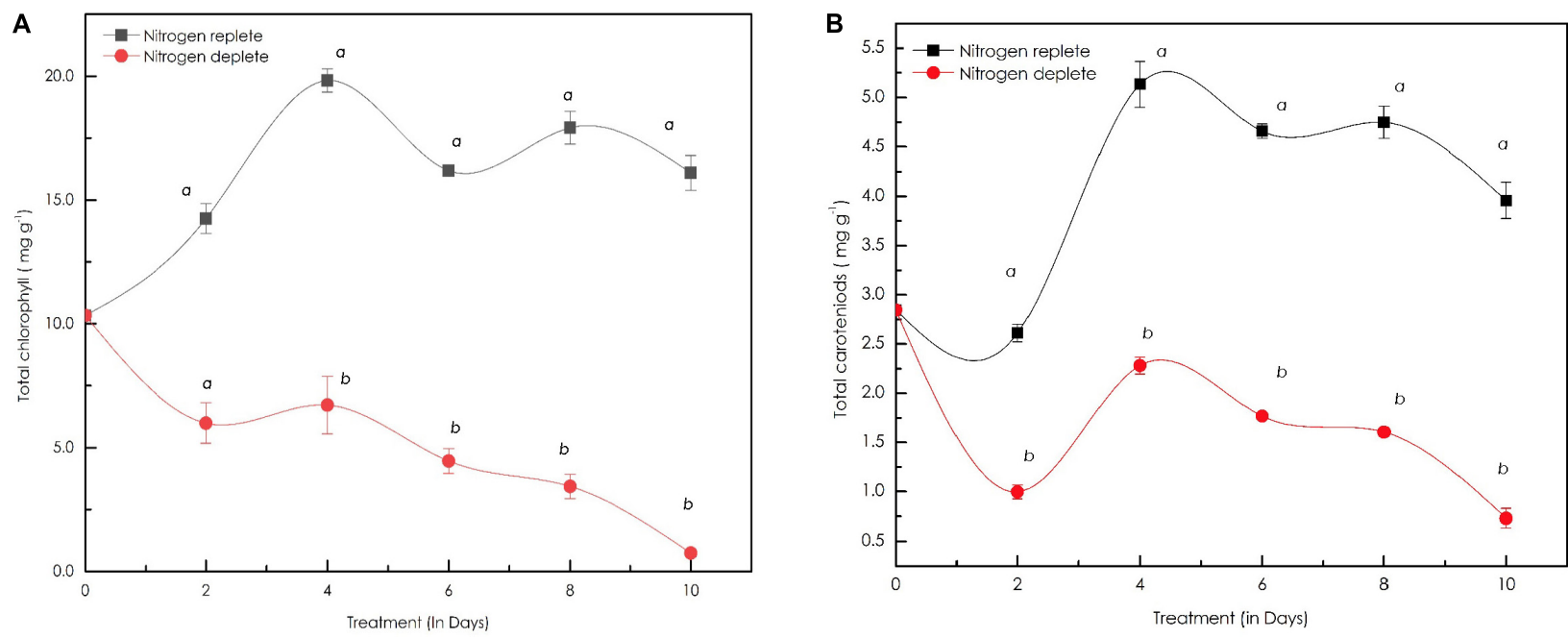

FIGURE 5 | (A) Line diagram representing the time-course dynamics of total chlorophyll content (in mg g $\mathrm{g}^{-1} \mathrm{dcw}$ ) in Monoraphidium sp. CABeR41 subjected to stress condition; (B) time-course variation in the total carotenoid content (in $\mathrm{mg} \mathrm{g}^{-1} \mathrm{dcw}$ ) of Monoraphidium sp. subjected to nutrient replete and deplete conditions. Statistical analysis was performed using one-way ANOVA with Fisher's LSD test and significance was determined if $p<0.05$. a and b both denotes the significant difference between the two conditions ( $a$, maximum; b, minimum).
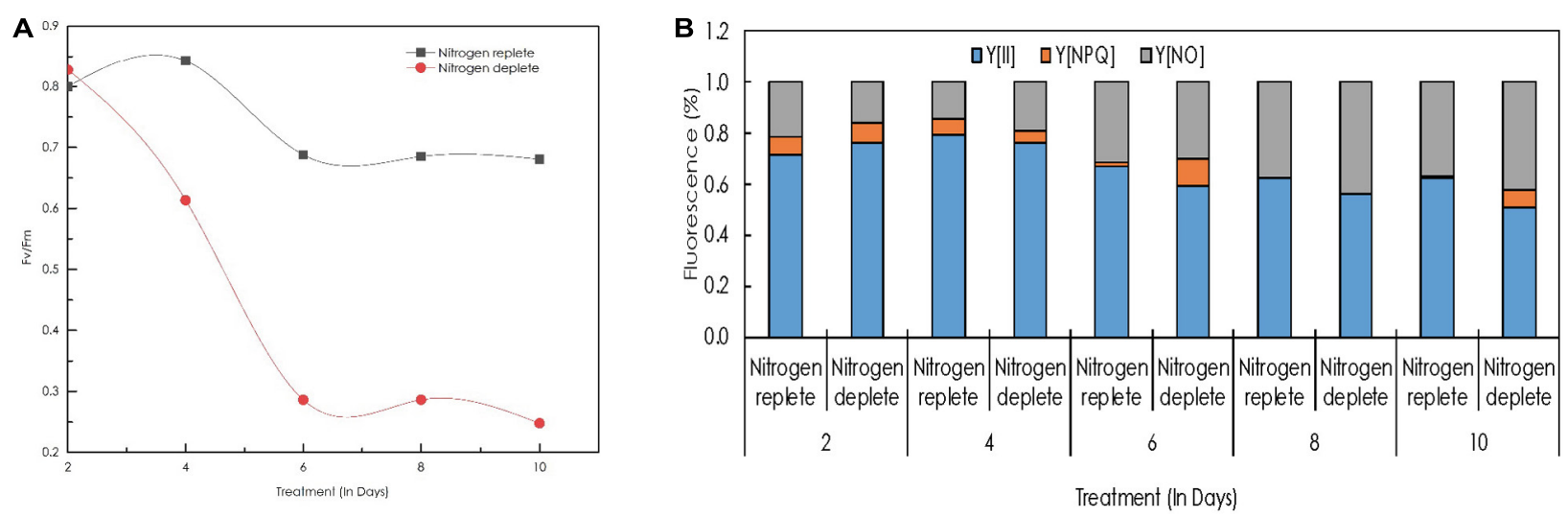

FIGURE 6 | (A) Line diagram indicating maximum quantum yield of the PSIl reaction centers $\left(F_{\mathrm{V}} / F_{\mathrm{m}}\right)$ in replete and deplete conditions; (B) quantum yields of photochemical quenching Y[II], non-photochemical quenching Y[NPQ], and the non-light induced energy dissipated as heat or fluorescence Y[NO] in Monoraphidium sp. CABeR41 subjected to nutrient deprivation. 
Time course changes with respect to quantum yields of photochemical quenching Y[II], non-photochemical quenching $\mathrm{Y}[\mathrm{NPQ}]$, and thermal energy dissipation in the form of heat and fluorescence occurring during a closed PSII system Y[NO] were also calculated (Figure 6B). The Y[II] of both the replete and deplete cells remained approximately similar until the 4 th day of cultivation, whereas a decrease was observed in deplete cells after the 4th day until the 10th day. The Y[II] of replete cells decreased after the 4th day but remained constant from the 6th to the 10th day as observed with the $F_{v} / F_{m}$ ratio. In addition, a significant increase in Y[NPQ] was also observed in nitrogen-deplete cells on the 10th day of cultivation.

\section{Fatty Acid Methyl Esters (FAMEs) Quantification and Profiling}

The FAME quantification and profiling of new indigenous isolate Monoraphidium sp. CABeR41 exhibits the following compositions: $22.4 \%$ of saturated fatty acids (SFA), $21.4 \%$ of monounsaturated fatty acid (MUFA), and 56.32\% of PUFA. In replete conditions, PUFA content slightly increases from $54.21 \%$ to $56.32 \%$ up to the 10 th day. Alpha linolenic acid [C18:3; ALA] (30.8\%), linoleic acid [C18:2] (18.9\%), and hexadecatrienoic acid [C16:3] (20.2\%) were prominent fatty acids (Table 2). Moreover, ALA is an important $\omega-3$ fatty acid in nature and was the most abundant fatty acid in Monoraphidium sp. CABeR41. During the stress-deplete condition, the strain shows an increase in MUFA $(29.28 \%$ to $38.71 \%$ of total FAME) and SFA (16.49\% to $27.74 \%$ of total FAME) (Table 2). Moreover, ALA content of Monoraphidium sp. CABeR41 declined from $29.95 \%$ to $20.02 \%$ of total FAME in deplete cells. It can be due to oxidative damage within the cells being stressed or membrane lipids (PUFAs) recycled into TAGs attributing toward membrane remodeling, further this was also confirmed by scanning electron images (SEM) in which irregular and ruptured cells observed on the 10th day of the nitrogen-deplete condition. However, oleic acid [C18:1] (29.5\%) and hexadecanoic acid [C16:0] (25.7\%) were

TABLE 2 | Total lipid profiles of Monoraphidium sp. CABeR41 subjected to nitrogen replete and deplete conditions on 10th day of cultivation.

\begin{tabular}{|c|c|c|}
\hline Fatty acids methyl esters (FAMEs) & $\begin{array}{l}\text { Nitrogen } \\
\text { replete }\end{array}$ & $\begin{array}{l}\text { Nitrogen } \\
\text { deplete }\end{array}$ \\
\hline Hexadecanoic acid (C16:0) (\%) & $20.2 \pm 4.5^{b}$ & $25.7 \pm 2.20^{\mathrm{a}}$ \\
\hline 9-Hexadecenoic acid (C16:1) (\%) & $2.4 \pm 0.66$ & $3.1 \pm 1.30$ \\
\hline 7,10-Hexadecadienoic acid (C16:2) (\%) & $1.3 \pm 0.94^{a}$ & $0.5 \pm 0.32^{b}$ \\
\hline 7,10,13-Hexadecatrienoic acid (C16:3) (\%) & $5.8 \pm 2.83$ & $3.2 \pm 1.42$ \\
\hline $\begin{array}{l}\text { Methyl 4,7,10,13-hexadecatetraenoate (C16:4) } \\
(\%)\end{array}$ & $8.4 \pm 2.85^{a}$ & $3.3 \pm 0.26^{b}$ \\
\hline Octadecanoic acid (C18:0) (\%) & $2.3 \pm 0.44^{\mathrm{b}}$ & $8.3 \pm 4.52^{\mathrm{a}}$ \\
\hline Oleic acid (C18:1) (\%) & $18.9 \pm 2.81$ & $29.5 \pm 5.51$ \\
\hline Linoleic acid (C18:2) (\%) & $10.0 \pm 0.17$ & $7.7 \pm 0.30$ \\
\hline$\gamma$-Linolenic acid (C18:3) (\%) & $30.8 \pm 0.39^{a}$ & $18.8 \pm 1.78^{\mathrm{b}}$ \\
\hline Saturated fatty acid (\% of total FAMEs) & $22.44 \pm 5.04^{b}$ & $33.96 \pm 9.64^{a}$ \\
\hline Monounsaturated fatty acid (\% of total FAME) & $21.24 \pm 6.72^{b}$ & $32.56 \pm 10.16^{a}$ \\
\hline Polyunsaturated fatty acid (\% of total FAMEs) & $56.32 \pm 3.04^{a}$ & $33.48 \pm 0.13^{b}$ \\
\hline Total FAME $\left(\mathrm{mg} \mathrm{g}^{-1}\right)$ & 4.8 & 6.9 \\
\hline
\end{tabular}

Statistical analysis was performed using one-way ANOVA with Fisher's LSD test, and significance was determined if $p<0.05$. $a$ and $b$ both denotes the significant difference between the two conditions ( $a$, maximum; $b$, minimum).

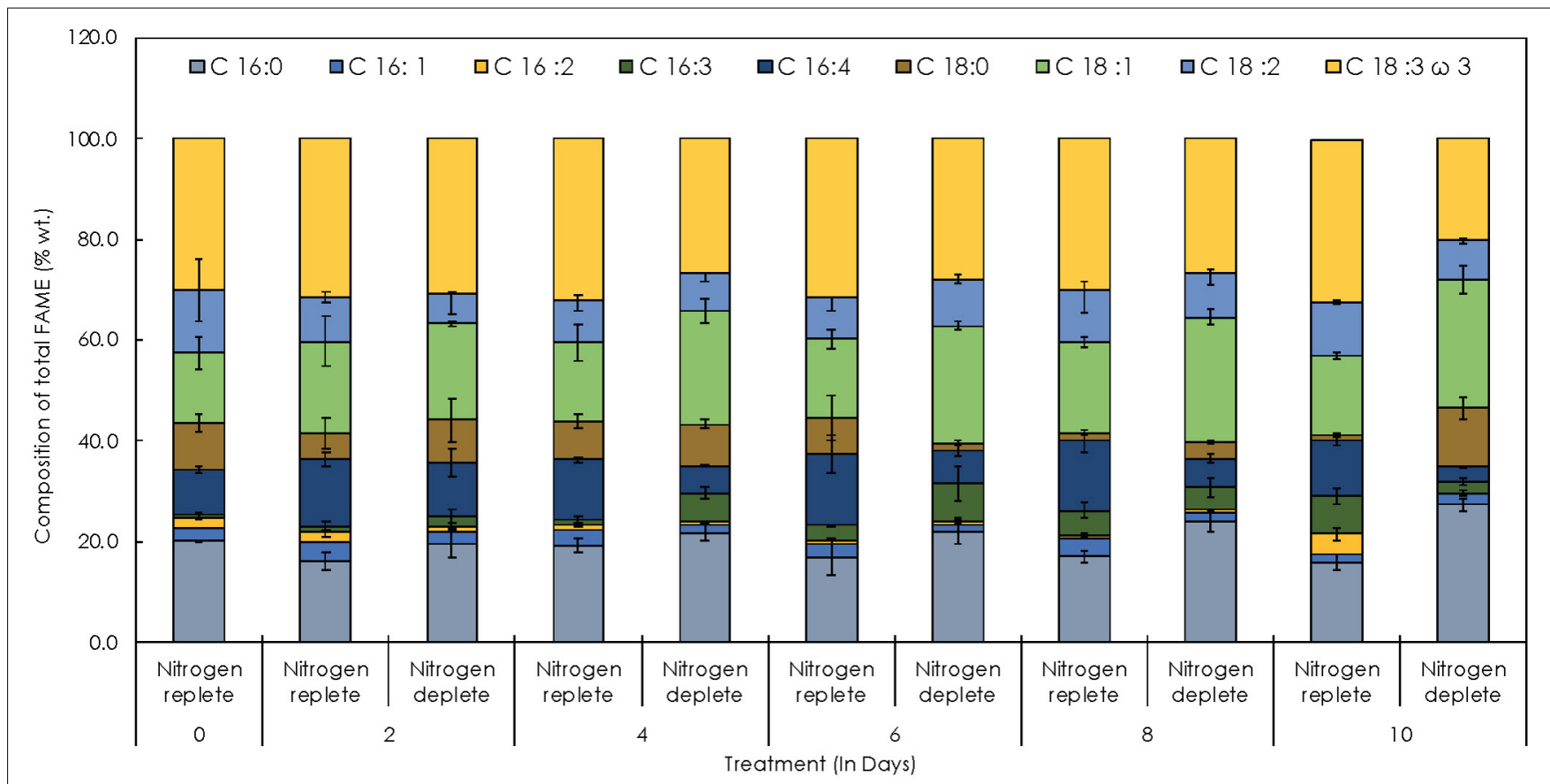

FIGURE 7 | Time-course FAME profiles depicting the distribution of individual fatty acids in Monoraphidium sp. CABeR41 subjected to nitrogen replete and deplete conditions. 

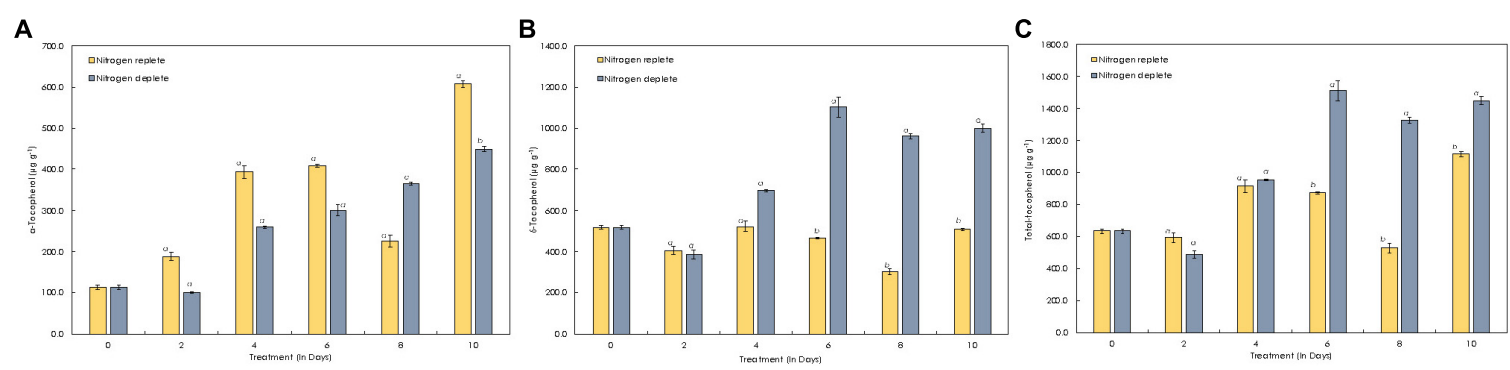

FIGURE 8 | Quantitative analysis of tocopherols in Monoraphidium sp. CABeR41 subjected to nitrogen stress. (A) $\alpha$-tocopherol; (B) $\delta$-tocopherol; and (C) total tocopherols. Statistical analysis was performed using one-way ANOVA with Fisher's LSD test, and significance was determined if $p<0.05$. a and b both denotes the significant difference between the two conditions ( $a$, maximum; b, minimum).

the major fatty acids during nitrogen depletion (Figure 7). In addition, the total FAME content in nitrogen-deplete conditions seems to be higher $\left(6.9 \mathrm{mg} \mathrm{g}^{-1} \mathrm{dcw}\right)$ than replete cells (4.8 $\left.\mathrm{mg} \mathrm{g}^{-1} \mathrm{dcw}\right)$.

\section{Qualitative and Quantitative Analysis of Tocopherols}

$\alpha$-Tocopherol content in this strain was estimated to be around $113.6 \mathrm{Mg} \mathrm{g}^{-1}$ of $\mathrm{dcw}$ initially (Figure 8A) and gradually increased to $607.8 \mu \mathrm{g} \mathrm{g}^{-1}$ of $\mathrm{dcw}$ by the 10 th day in the replete conditions. However, almost similar trends observed with $\delta$-tocopherol (reporting for the first time in Monoraphidium sp.) with increase to $496.5 \mu \mathrm{g} \mathrm{g}^{-1}$ of $\mathrm{dcw}$ by the 10 th day. During nitrogen starvation, $\alpha$-tocopherol levels are lower as compared to control conditions, but the trend remains similar. $\alpha$-tocopherol during the nutrient stress-deplete condition initially declines from $113.6 \mu \mathrm{g} \mathrm{g}^{-1}$ of dcw to $99.48 \mu \mathrm{g} \mathrm{g}^{-1}$ of $\mathrm{dcw}$ in first 2 days and later increased to $450.15 \mu \mathrm{g} \mathrm{g}^{-1}$ of $\mathrm{dcw}$ on the 10th day. Whereas the $\delta$-tocopherol levels reached up to $1000.09 \mu \mathrm{g} \mathrm{g}^{-1}$ of $\mathrm{dcw}$ by the 10th day (Figure 8B). In addition, the totaltocopherol content increased from $632.8 \mu \mathrm{g} \mathrm{g}^{-1}$ of $\mathrm{dcw}$ to $1115.5 \mu \mathrm{g} \mathrm{g}^{-1}$ of $\mathrm{dcw}$ by the 10th day of cultivation in the replete cells, whereas in the deplete condition, the levels reached up to $1400 \mu \mathrm{g} \mathrm{g}^{-1}$ of dcw with a fold change of 1.14 (Figure 8C and Table 3).

TABLE 3 | Tocopherol yields and productivity of Monoraphidium sp. CABeR41 in nutrient replete and deplete conditions on the 10th day of cultivation.

\begin{tabular}{lcc}
\hline Types of tocopherols & Nitrogen replete & Nitrogen deplete \\
\hline$\alpha$-Tocopherol $\left(\mu \mathrm{g} \mathrm{g}^{-1}\right)$ & $607.86 \pm 8.03^{\mathrm{a}}$ & $450.15 \pm 6.00^{\mathrm{b}}$ \\
$\alpha$-Tocopherol $\left(\mu \mathrm{g} \mathrm{L}^{-1} \mathrm{~d}^{-1}\right)$ & $28.44 \pm 0.06$ & $8.86 \pm 0.01$ \\
$\delta$-Tocopherol $\left(\mu \mathrm{g} \mathrm{g}^{-1}\right)$ & $507.18 \pm 7.50^{\mathrm{b}}$ & $1000.09 \pm 18.4^{\mathrm{a}}$ \\
$\delta$-Tocopherol $\left(\mu \mathrm{g} \mathrm{L}^{-1} \mathrm{~d}^{-1}\right)$ & $20.71 \pm 0.06$ & $17.93 \pm 0.02$ \\
Total tocopherols $\left(\mu \mathrm{g} \mathrm{g}^{-1}\right)$ & $1115.05 \pm 15.8^{\mathrm{b}}$ & $1450.24 \pm 24.10^{\mathrm{a}}$ \\
Total tocopherols $\left(\mu \mathrm{g} \mathrm{L}^{-1} \mathrm{~d}^{-1}\right)$ & $49.15 \pm 0.12$ & $26.79 \pm 0.3$ \\
\hline
\end{tabular}

Statistical analysis was performed using one-way ANOVA with Fisher's LSD test, and significance was determined if $p<0.05$. $a$ and $b$ both denotes the significant difference between the two conditions ( $a$, maximum; $b$, minimum).

\section{DISCUSSION AND CONCLUSION}

The inherent ability of microalgae to synthesize HVABs makes these photosynthetic cell factories an important source of feed material. Moreover, such bioactive molecules are of great interest in the nutraceutical and cosmetics industries. In the current scenario, due to the rapid exploration of natural HVABs, the development of the health-management paradigm focuses on general immune system regulation and the improvement of specific immune functions. Microalgae are relatively high in content and diversity of HVABs, which are more potent than plants for the antioxidant efficacy of microalgae (Sansone and Brunet, 2019). HVAB accumulation is associated with variables, such as $\mathrm{C}, \mathrm{N}, \mathrm{P}$, and $\mathrm{S}$ and may also contribute to a higher biomass and lower quality of HVABs. Similarly, discovering natural HVAB resources and improving yields are the future priorities for sustainable algal refineries.

In the current study, the microalgal strain was isolated from freshwater springs near Dharamshala, Himachal Pradesh, India, at the elevation of 6,831 feet above sea level. The sample was collected in autumn when temperatures range between $30^{\circ} \mathrm{C}$ and $0^{\circ} \mathrm{C}$. The microalgae isolated from such environmental zones show higher adaptability unique to their habitats and genetic architecture producing specific metabolites, such as HVABs in adverse conditions to overcome and acclimatize to the biotic and/or abiotic stress conditions. Therefore, microalgal bioprospecting is an approach to evaluate and analyze the potential of these algal strains for sustainable development in biorefineries.

The newly isolated microalga Monoraphidium sp. is a fastgrowing strain with a growth rate of $0.20 \mathrm{~d}^{-1}$ and biomass productivity of $60.56 \mathrm{mg} \mathrm{L}^{-1} \mathrm{~d}^{-1}$, which is higher than other reported strains of Monoraphidium sp. (Monoraphidium sp. QLY1; $29.1 \mathrm{mg} \mathrm{L}^{-1} \mathrm{~d}^{-1}$, Monoraphidium sp. QLZ-3; $30.3 \mathrm{mg} \mathrm{L}^{-1}$ $\mathrm{d}^{-1}$, Monoraphidium sp. YLY-2; $10.5 \mathrm{mg} \mathrm{L}^{-1} \mathrm{~d}^{-1}$ ) (Zhao et al., 2016), Monoraphidium sp. KMN5; $13.0 \mathrm{mg} \mathrm{L}^{-1} \mathrm{~d}^{-1}$ ) (Tale et al., 2014), Monoraphidium sp. HDMA-20; $36.3 \mathrm{mg} \mathrm{L}^{-1} \mathrm{~d}^{-1}$ ) (Lin et al., 2019). A recent study by our group involving Parachlorella kessleri subjected to a nitrogen stress condition demonstrates that the photosynthetic activity ceases affecting the phosphorus absorption, and cells shut down energy-expensive metabolisms, such as protein synthesis, by diverting the carbon flux to 
energy storage metabolites, such as lipids and/or carbohydrates (Shaikh et al., 2019). Similarly, in the present study, growth was severely affected during the nitrogen-deplete condition, and a simultaneous decline in protein content was observed after the 4th day. The decline in growth was also accompanied by the loss of chloroplasts and massive damage to the photosynthetic machinery. The protein content was significantly reduced in nitrogen starvation, which may be due to reduced NADPH levels inhibiting the amino acid biosynthesis, specifically the conversion of $\alpha$-ketoglutarate to glutamate (Kudahettige et al., 2018), similar to a study reporting the same effect of nitrate depletion on protein content in Acutodesmus dimorphus (Chokshi et al., 2017). Also, our data show a significant increase in carbohydrate content until the 6th day in deplete conditions (a threefold change) that decreased later due to diversion of carbons toward lipids under prolonged nutritional stress. Likewise, elevated lipid accumulation was also observed on the 10th day of cultivation in nitrogen-starved cells. An increase in lipid content when subjected to nitrate limitation has been exhibited in microalgal strains, such as $P$. kessleri, Monoraphidium sp., Chlorella zofingiensis (Feng et al., 2012; Zhao et al., 2018; Shaikh et al., 2019). The morphology of the cells in nitrogen stress indicates changes in the form and size after the 4 th day of starvation as confirmation by the NR microscopy by dwindling and acquiring lipids. Perhaps the NR staining of lipid bodies in nitrogen starvation is reported to enhance cells' neutral lipids, which is quite well documented.

In a nutrient-deprived environment, the total amount of chlorophyll declined as stress continued during the days, which could show signs of cell senescence. Chlorophyll molecules are likely to contain four nitrogen molecules within their form, rendering it much tougher for organelles in the absence of nitrogen to synthesize certain compounds as previously reported in Chlorella vulgaris (Ikaran et al., 2015; Janchot et al., 2019). Moreover, the maximum quantum efficiency $F_{v} / F_{m}$ of PSII reaction centers in the stress cells of the deplete condition also observed a sharp decline reaching to $0.24 F_{v} / F_{m}$ on the 10th day, indicating that photosynthetic functioning inside the cells are highly deteriorated and stress might lead to decrease in $F_{v} / F_{m}$ ratio as demonstrated in Chlorella sp. (White et al., 2011). In addition, downregulation of the light-harvesting complexes in stressed cells also contributes to reduced photosynthetic efficiency (Miller et al., 2010). Also, the decrease in $F_{v} / F_{m}$ ratio is attributed by inhibition of the electron transport change from both the donor and acceptor sites of the PSII reaction center, further promoting the diversion of excitation energy toward PSI, resulting in elevated electron flow toward PSI. Moreover the decrease in the electron flow represents the adaptive acclimation to downregulate PSII so as to dissipate the excess energy from the photosystem to maintain the oxidative state of $\mathrm{Q}_{\mathrm{A}}$ (Lu and Vonshak, 2002).

The energy dissipation $\mathrm{Y}[\mathrm{NO}]$ also tends to be increasing more in deplete-condition cells after the 4th day, indicating that replete cells are functioning actively toward photochemical reactions. Moreover $\mathrm{Y}[\mathrm{NO}]$ is defined as a simple indicator for reduced plastoquinone status within photosynthetic membranes, but for high-irradiance microalgae, it is seen that the lower plastoquinone status is minimized, suggesting that the photochemical reactions in normal cells are much more efficient and able to regulate the transportation of photosynthetic electrons compared to the nitrogen-starved cells (Grieco et al., 2012; Nawrocki et al., 2020). During a stress phenomenon the increase in $\mathrm{Y}[\mathrm{NO}]$ is accompanied by inactivation of PSII reaction centers, which dissipate excitation energy into heat (Maxwell and Johnson, 2000). A decrease in the $F_{v} / F_{m}$ ratio is also triggered by photo inactivation leading to oxidative damage and loss of PSII reaction centers (Baker, 2008). Moreover, the significant increase in Y[NPQ] in the nutrient-deplete condition on the 10th day, reveals that harvested light is dissipated as thermal energy due to inefficient photosynthetic apparatus, which attributes toward the defensive mechanism of the cell (White et al., 2011).

Nitrogen starvation modulates the production of tocopherols and lipids and induces morphological changes in Monoraphidium sp. CABeR41. In addition, we hypothesize that fatty acids are differentially regulated in stress conditions with an increase in fatty acid content. Major changes occurred in the decline of PUFAs and increase in the SFAs and MUFAs making the profile ideal toward biodiesel properties (Huerlimann et al., 2010). With higher PUFAs, the longer the ignition delay, resulting in retarded combustion, moreover decreasing oxidation stability and raising NOx emission (Benjumea et al., 2011). However, there are a number of reports highlighting the biodiesel potential of the Monoraphidium sp. (Patidar et al., 2014) reported fatty acid profile rich in SFA (30.92\%-68.94\% of total FAME) with biomass productivity of $\left(80.3-303.8 \mathrm{mg} \mathrm{L}^{-1} \mathrm{~d}^{-1}\right)$ and total lipid $(22.08 \%-46.54 \%$ of total FAME) under mixotrophic conditions. Similarly, less than $0.36 \mathrm{~g} \mathrm{~L}^{-1}$ of the nitrate Monoraphidium sp. exhibited the lipid productivity of $0.18 \mathrm{~g} \mathrm{~L}^{-1} \mathrm{~d}^{-1}$ with fatty acid compositions (SFA; 37.22\%, MUFA; 39.19\%, PUFA; $26.30 \%$ of total FAME), making it suitable toward biodiesel (Dhup and Dhawan, 2014). Also, M. contortum is reported with biomass productivity of $896.0 \mathrm{mg} \mathrm{L}^{-1} \mathrm{~d}^{-1}$ with neutral lipid accumulation of $20.4 \%$ of dcw under nitrogen deplete. Moreover, there are no studies based on tocopherol accumulation in other Monoraphidium sp. Few other strains are reported, such as Chlorella sp. with biomass productivity of $55.6 \mathrm{mg} \mathrm{L}^{-1} \mathrm{~d}^{-1}$ and $\sim 18 \%$ dcw of lipids (Kassim and Meng, 2017), Scenedesmus sp. CCNM 1077 with biomass productivity of $22.7 \mathrm{mg} \mathrm{L}^{-1} \mathrm{~d}^{-1}$ and $\sim 18.9 \%$ dcw of lipids (Pancha et al., 2015) and Nannochlropsis sp. with lipid productivity of $44.2 \mathrm{mg} \mathrm{L}^{-1} \mathrm{~d}^{-1}$ and $\sim 27.68 \% \mathrm{dcw}$ of lipids (Meng et al., 2015). In the present study, Monoraphidium sp. CABeR41 showed biomass productivity of $62.6 \mathrm{mg} \mathrm{L}^{-1}$ $\mathrm{d}^{-1}$ with $\sim 16.5 \% \mathrm{dcw}$ of lipids, which is competitive in terms of previously defined potent strains for biofuel production, and the relationship also enhances the value with co-products, such as tocopherols.

During photoautotrophic growth and development, tocopherol levels are dramatically increasing as a result of the alteration in expression of pathway genes, degradation, and recycling in response to environmental stresses. In addition, it was also found that an increase in tocopherol accumulation contributes to stress tolerance by limiting ROS generation while 
a decrease in the tocopherol levels may cause oxidative damage (Hasanuzzaman et al., 2014). A study has shown a tocopheroldeficient mutant (vte1) in Arabidopsis thaliana shows similar growth and photosynthetic efficiency in the control condition, whereas during photo-oxidative stress, chlorophyll content and photosynthetic quantum yield were severely affected in (vte1), indicating the role of tocopherol in maintaining photosynthetic efficiency (Porfirova et al., 2002).

In N. oculata, reduced nitrogen levels contribute to an increase in accumulation of $\alpha$-tocopherol with a decreased growth rate. Further, $\alpha$-tocopherol content was dependent on factors like nitrogen source, concentration, and phase of development (Durmaz, 2007). Reports show accumulation of $\alpha$-tocopherol up to $2.3 \mathrm{mg} \mathrm{g}^{-1} \mathrm{dcw}$ in N. oculata and $2.6 \mathrm{mg} \mathrm{g}^{-1} \mathrm{dcw}$ in Euglena gracilis (Fujita et al., 2008), respectively; however, until now, there have been no reports of $\delta$-tocopherol production among microalgae. Our study is the first to report both $\alpha$ and $\delta$-tocopherol accumulation in Monoraphidium sp. CABeR41 with an adequate amount of total tocopherol accumulation $\left(1.4 \mathrm{mg} \mathrm{g}^{-1} \mathrm{dcw}\right)$ in nitrogen-deplete conditions. Henceforth, we hypothesize that, in stressed cells, the carbon flux is majorly diverted toward 2-methyl-6-phytyl-1,4-benzoquinone (MPBQ) rather than 2,3-dimethyl-6-phytyl-1,4-benzoquinone (DMPBQ), which is utilized by tocopherol cyclase producing a 0.6 -fold increase in $\delta$-tocopherol compared to $\alpha$-tocopherol. Furthermore, stressed cells show a decrease in $\delta$-tocopherol content after the 6th day, and this might be due to the fact that tocopherols are degraded and recycled as the concentration of ROS increases in the chloroplasts (Munné-Bosch and Alegre, 2002). In addition, there is a decrease in productivity due to a declined growth rate, and previous reports observed that productivity of both $\alpha$-tocopherol and total fatty acid increases dramatically when cultivations were gassed with $5 \% \mathrm{CO}_{2}(\mathrm{v} / \mathrm{v})$ in Coccomyxa sp., Desmodesmus sp., and Muriella terrestris. Since our strain was aerated with atmospheric air, there is room for enhancement of FA and total tocopherols via enrichment of the overhead atmosphere with the external $\mathrm{CO}_{2}$ supply. Additionally, optimization of cultivation conditions and the reduction of production cost strategies can be employed in the future with flue gas supply and two-stage cultivation for enhanced productivity. Though adequate stress conditions, like depletion of

\section{REFERENCES}

Agarwal, A., Patil, S., Gharat, K., Pandit, R. A., and Lali, A. M. (2019). Modulation in light utilization by a microalga Asteracys sp. under mixotrophic growth regimes. Photosynth. Res. 139, 553-567. doi: 10.1007/s11120-018-0526-8

Ahsan, H., Ahad, A., Iqbal, J., and Siddiqui, W. A. (2014). Pharmacological potential of tocotrienols: a review. Nutr. Metab. 11:52. doi: 10.1186/1743-707511-52

Baker, N. R. (2008). Chlorophyll fluorescence: a probe of photosynthesis in vivo. Annu. Rev. Plant Biol. 59, 89-113. doi: 10.1146/annurev.arplant.59.032607. 092759

Benjumea, P., Agudelo, J. R., and Agudelo, A. F. (2011). Effect of the degree of unsaturation of biodiesel fuels on engine performance, combustion characteristics, and emissions. Energ. Fuel. 25, 77-85. doi: 10.1021/ef101096x

Borowitzka, M. A. (2013). High-value products from microalgae-their development and commercialisation. J. Appl. Phycol. 25, 743-756. doi: 10.1007/s10811-013-9983-9 nitrogen, high light, and high salinity, stimulate the synthesis and accumulation of HVABs. Recent advances in integrated omics enhance research perspectives in understanding gene regulation and molecular mechanism in different stress conditions, which provide insights in further enhancement of HVAB accumulation through sustainable strategies.

\section{DATA AVAILABILITY STATEMENT}

The datasets presented in this study can be found in online repositories. The names of the repository/repositories and accession number(s) can be found below: NCBI (accession number: MT622543).

\section{AUTHOR CONTRIBUTIONS}

RS, AAN, and PJ designed the experiments. RS and CP executed the experiments. AN and PJ supervised the project. RS, CP, and AAN wrote the manuscript with all the input from the authors. All authors read and approved the final manuscript.

\section{FUNDING}

The work was supported by grants from the Department of Biotechnology, Government of India, to PJ (Sanction Nos. BT/PB/Center/03/2011 and BT/PR16512/BID/7/647/2016), and to AAN (BioCARe Scheme No. BT/PR18491/BIC/101/759/2016). Senior Research Fellowship to RS from the Department of Biotechnology and N-PDF (Sanction No. PDF/2018/001547) to $\mathrm{CP}$ from the Science and Engineering Research Board (SERB), Government of India, is duly acknowledged.

\section{ACKNOWLEDGMENTS}

We would like to thank Mr. Girish H. Rajacharya (Technical Manager, ICGEB) for providing support with analytical instrumentation.

Chen, Y., Xu, C., and Vaidyanathan, S. (2018). Microalgae: a robust "green biobridge" between energy and environment. Crit. Rev. Biotechnol. 38, 351-368. doi: 10.1080/07388551.2017.1355774

Chokshi, K., Pancha, I., Ghosh, A., and Mishra, S. (2017). Nitrogen starvationinduced cellular crosstalk of ROS-scavenging antioxidants and phytohormone enhanced the biofuel potential of green microalga Acutodesmus dimorphus. Biotechnol. Biofuels 10:60. doi: 10.1186/s13068-017-0747-7

Cirulis, J. T., Scott, J. A., and Ross, G. M. (2013). Management of oxidative stress by microalgae. Can. J. Physiol. Pharmacol. 91, 15-21. doi: 10.1139/cjpp-20120249

Collos, Y., Mornet, F., Sciandra, A., Waser, N., Larson, A., and Harrison, P. J. (1999). An optical method for the rapid measurement of micromolar concentrations of nitrate in marine phytoplankton cultures. J. Appl. Phycol. 11, 179-184. doi: 10.1023/A:1008046023487

Cooksey, K. E., Guckert, J. B., Williams, S. A., and Callis, P. R. (1987). Fluorometric determination of the neutral lipid content of microalgal cells using Nile Red. J. Microbiol. Methods 6, 333-345. doi: 10.1016/0167-7012(87)90019-4 
Dhup, S., and Dhawan, V. (2014). Effect of nitrogen concentration on lipid productivity and fatty acid composition of Monoraphidium sp. Bioresour. Technol. 152, 572-575. doi: 10.1016/j.biortech.2013.11.068

Di Rienzo, J. A., Casanoves, F., Balzarini, M. G., González, L., Tablada, M., and Robledo, Y. C. (2011). InfoStat Versión 2011. Available: https://www.infostat. com.ar/ (accessed June 10, 2020).

Durmaz, Y. (2007). Vitamin E ( $\alpha$-tocopherol) production by the marine microalgae Nannochloropsis oculata (eustigmatophyceae) in nitrogen limitation. Aquaculture 272, 717-722. doi: 10.1016/j.aquaculture.2007.07.213

Edgar, R. C. (2004). MUSCLE: a multiple sequence alignment method with reduced time and space complexity. BMC Bioinform. 5:113. doi: 10.1186/1471-21055-113

Feng, P., Deng, Z., Fan, L., and Hu, Z. (2012). Lipid accumulation and growth characteristics of Chlorella zofingiensis under different nitrate and phosphate concentrations. J. Biosci. Bioeng. 114, 405-410. doi: 10.1016/j.jbiosc.2012. 05.007

Fritsche, S., Wang, X., Li, J., Stich, B., Kopisch-Obuch, F. J., Endrigkeit, J., et al. (2012). A candidate gene-based association study of tocopherol content and composition in rapeseed (Brassica napus). Front. Plant Sci. 3:129. doi: 10.3389/ fpls.2012.00129

Fujita, T., Aoyagi, H., Ogbonna, J. C., and Tanaka, H. (2008). Effect of mixed organic substrate on alpha-tocopherol production by Euglena gracilis in photoheterotrophic culture. Appl. Microbiol. Biotechnol. 79, 371-378. doi: 10. 1007/s00253-008-1443-0

Gao, Y., Feng, J., Lv, J., Liu, Q., Nan, F., Liu, X., et al. (2019). Physiological changes of Parachlorella kessleri TY02 in lipid accumulation under nitrogen stress. Int. J. Environ. Res. Public. Health 16:1188. doi: 10.3390/ijerph1607 1188

Ghafari, M., Rashidi, B., and Haznedaroglu, B. Z. (2018). Effects of macro and micronutrients on neutral lipid accumulation in oleaginous microalgae. Biofuels 9, 147-156. doi: 10.1080/17597269.2016.1221644

Grieco, M., Tikkanen, M., Paakkarinen, V., Kangasjarvi, S., and Aro, E. M. (2012). Steady-state phosphorylation of light-harvesting complex II proteins preserves photosystem I under fluctuating white light. Plant Physiol. 160, 1896-1910. doi: 10.1104/pp.112.206466

Hall, B. G. (2013). Building phylogenetic trees from molecular data with MEGA. Mol. Biol. Evol. 30, 1229-1235. doi: 10.1093/molbev/mst012

Hasanuzzaman, M., Nahar, K., and Fujita, M. (2014). "Role of tocopherol (vitamin E) in plants: abiotic stress tolerance and beyond," in Emerging Technologies and Management of Crop Stress Tolerance, eds P. Ahmad, and S. Rasool (San Diego, CA: Academic Press), 267-289. doi: 10.1016/B978-0-12-800875-1.00012-0

Huerlimann, R., De Nys, R., and Heimann, K. (2010). Growth, lipid content, productivity, and fatty acid composition of tropical microalgae for scale-up production. Biotechnol. Bioeng. 107, 245-257. doi: 10.1002/bit.22809

Ikaran, Z., Suárez-Alvarez, S., Urreta, I., and Castañón, S. (2015). The effect of nitrogen limitation on the physiology and metabolism of Chlorella vulgaris var L3. Algal Res. 10, 134-144. doi: 10.1016/j.algal.2015.04.023

Janchot, K., Rauytanapanit, M., Honda, M., Hibino, T., Sirisattha, S., Praneenararat, T., et al. (2019). Effects of potassium chloride-induced stress on the carotenoids canthaxanthin, astaxanthin, and lipid accumulations in the green chlorococcal microalga strain TISTR 9500. J. Eukaryot. Microbiol. 66, 778-787. doi: $10.1111 /$ jeu. 12726

Kareya, M. S., Mariam, I., Shaikh, K. M., Nesamma, A. A., and Jutur, P. P. (2020). Photosynthetic carbon partitioning and metabolic regulation in response to very-low and high $\mathrm{CO}_{2}$ in Microchloropsis gaditana NIES 2587. Front. Plant Sci. 11:981. doi: 10.3389/fpls.2020.00981

Kassim, M. A., and Meng, T. K. (2017). Carbon dioxide $\left(\mathrm{CO}_{2}\right)$ biofixation by microalgae and its potential for biorefinery and biofuel production. Sci. Total Environ. 584-585, 1121-1129. doi: 10.1016/j.scitotenv.2017.01.172

Kudahettige, N. P., Pickova, J., and Gentili, F. G. (2018). Stressing algae for biofuel production: biomass and biochemical composition of Scenedesmus dimorphus and Selenastrum minutum grown in municipal untreated wastewater. Front. Energy Res. 6:132. doi: 10.3389/fenrg.2018.00132

Lambrecht, E., Baré, J., Claeys, M., Chavatte, N., Bert, W., Sabbe, K., et al. (2015). Transmission electron microscopy sample preparation protocols for the ultrastructural study of cysts of free-living protozoa. Biotechniques 58, 181-188. doi: $10.2144 / 000114274$
Lee, K., Eisterhold, M. L., Rindi, F., Palanisami, S., and Nam, P. K. (2014). Isolation and screening of microalgae from natural habitats in the midwestern United States of America for biomass and biodiesel sources. J. Nat. Sc. Biol. Med. 5, 333-339. doi: 10.4103/0976-9668.136178

Lichtenthaler, H. K., and Buschmann, C. (2001). Chlorophylls and carotenoids: measurement and characterization by UV-VIS spectroscopy. Curr. Protocols Food Anal. Chem. 1:48. doi: 10.1002/0471142913.faf0403s01

Lin, Y., Ge, J., Zhang, Y., Ling, H., Yan, X., and Ping, W. (2019). Monoraphidium sp. HDMA-20 is a new potential source of $\alpha$-linolenic acid and eicosatetraenoic acid. Lipids Health Dis. 18:56. doi: 10.1186/s12944-019-0996-5

Lu, C., and Vonshak, A. (2002). Effects of salinity stress on photosystem II function in cyanobacterial Spirulina platensis cells. Physiol. Plant. 114, 405-413. doi: 10.1034/j.1399-3054.2002.1140310.x

Lv, J., Yang, X., Ma, H., Hu, X., Wei, Y., Zhou, W., et al. (2015). The oxidative stability of microalgae oil (Schizochytrium aggregatum) and its antioxidant activity after simulated gastrointestinal digestion: relationship with constituents. Eur. J. Lipid Sci. Technol. 117, 1928-1939. doi: 10.1002/ejlt. 201400588

Maxwell, K., and Johnson, G. N. (2000). Chlorophyll fluorescence-a practical guide. J. Exper. Bot. 51, 659-668.1.

Meier, U. (2006). A note on the power of Fisher's least significant difference procedure. Pharmaceut. Statist. 5, 253-263. doi: 10.1002/pst.210

Meng, Y., Jiang, J., Wang, H., Cao, X., Xue, S., Yang, Q., et al. (2015). The characteristics of TAG and EPA accumulation in Nannochloropsis oceanica IMET1 under different nitrogen supply regimes. Bioresour. Technol. 179, 483489. doi: 10.1016/j.biortech.2014.12.012

Miller, R., Wu, G., Deshpande, R. R., Vieler, A., Gärtner, K., Li, X., et al. (2010). Changes in transcript abundance in Chlamydomonas reinhardtii following nitrogen deprivation predict diversion of metabolism. Plant Physiol. 154, 17371752. doi: 10.1104/pp.110.165159

Mishra, S. K., Suh, W. I., Farooq, W., Moon, M., Shrivastav, A., Park, M. S., et al. (2014). Rapid quantification of microalgal lipids in aqueous medium by a simple colorimetric method. Bioresour. Technol. 155, 330-333.1.

Moltó-Puigmartí, C., Castellote, A. I., and López-Sabater, M. C. (2009). Ultrahigh-pressure liquid chromatographic method for the analysis of tocopherols in human colostrum and milk. J. Chromatogr. A 1216, 4388-4394. doi: 10.1016/ j.chroma.2009.02.088

Mudimu, O., Koopmann, I. K., Rybalka, N., Friedl, T., Schulz, R., and Bilger, W. (2017). Screening of microalgae and cyanobacteria strains for $\alpha$-tocopherol content at different growth phases and the influence of nitrate reduction on $\alpha$-tocopherol production. J. Appl. Phycol. 29, 2867-2875. doi: 10.1007/s10811017-1188- 1

Munné-Bosch, S., and Alegre, L. (2002). Interplay between ascorbic acid and lipophilic antioxidant defences in chloroplasts of water-stressed Arabidopsis plants. FEBS Lett. 524, 145-148. doi: 10.1016/s0014-5793(02)03041-7

Nawrocki, W. J., Liu, X., and Croce, R. (2020). Chlamydomonas reinhardtii exhibits de facto constitutive NPQ capacity in physiologically relevant conditions. Plant Physiol. 182, 472-479. doi: 10.1104/pp.19.00658

Ogbonna, J. C., Tomiyamal, S., and Tanaka, H. (1998). Heterotrophic cultivation of Euglena gracilis $\mathrm{Z}$ for efficient production of $\alpha$-tocopherol. J. Appl. Phycol. 10, 67-74. doi: 10.1023/A:1008011201437

Paliwal, C., Ghosh, T., George, B., Pancha, I., Maurya, R., Chokshi, K., et al. (2016). Microalgal carotenoids: potential nutraceutical compounds with chemotaxonomic importance. Algal Res. 15, 24-31. doi: 10.1016/j.algal.2016. 01.017

Paliwal, C., Pancha, I., Ghosh, T., Maurya, R., Chokshi, K., Vamsi Bharadwaj, S. V., et al. (2015). Selective carotenoid accumulation by varying nutrient media and salinity in Synechocystis sp. CCNM 2501. Bioresour. Technol. 197, 363-368. doi: 10.1016/j.biortech.2015.08.122

Pancha, I., Chokshi, K., Maurya, R., Trivedi, K., Patidar, S. K., Ghosh, A., et al. (2015). Salinity induced oxidative stress enhanced biofuel production potential of microalgae Scenedesmus sp. CCNM 1077. Bioresour. Technol. 189, 341-348. doi: 10.1016/j.biortech.2015.04.017

Patidar, S., Mitra, M., George, B., Soundarya, R., and Mishra, S. (2014). Potential of Monoraphidium minutum for carbon sequestration and lipid production in response to varying growth mode. Bioresour. Technol. 172C, 32-40. doi: 10.1016/j.biortech.2014.08.070 
Pérez-Pérez, M. E., Lemaire, S. D., and Crespo, J. L. (2012). Reactive oxygen species and autophagy in plants and algae. Plant Physiol. 160, 156-164. doi: 10.1104/pp.112.199992

Poljšak, B., and Fink, R. (2014). The protective role of antioxidants in the defence against ROS/RNS-mediated environmental pollution. Oxid. Med. Cell Longev. 2014:671539. doi: 10.1155/2014/671539

Porfirova, S., Bergmuller, E., Tropf, S., Lemke, R., and Dormann, P. (2002). Isolation of an Arabidopsis mutant lacking vitamin $\mathrm{E}$ and identification of a cyclase essential for all tocopherol biosynthesis. Proc. Natl. Acad. Sci. U.S.A. 99, 12495-12500. doi: 10.1073/pnas.182330899

Saitou, N., and Nei, M. (1987). The neighbor-joining method: a new method for reconstructing phylogenetic trees. Mol. Biol. Evol. 4, 406-425. doi: 10.1093/ oxfordjournals.molbev.a040454

Sansone, C., and Brunet, C. (2019). Promises and challenges of microalgal antioxidant production. Antioxidants 8:antiox8070199. doi: 10.3390/ antiox8070199

Shaikh, K. M., Nesamma, A. A., Abdin, M. Z., and Jutur, P. P. (2019). Molecular profiling of an oleaginous trebouxiophycean alga Parachlorella kessleri subjected to nutrient deprivation for enhanced biofuel production. Biotechnol. Biofuels 12:182. doi: 10.1186/s13068-019-1521-9

Simionato, D., Block, M. A., La Rocca, N., Jouhet, J., Maréchal, E., Finazzi, G., et al. (2013). The response of Nannochloropsis gaditana to nitrogen starvation includes de novo biosynthesis of triacylglycerols, a decrease of chloroplast galactolipids, and reorganization of the photosynthetic apparatus. Eukaryot. Cell 12, 665-676. doi: 10.1128/EC.00363-12

Skjånes, K., Rebours, C., and Lindblad, P. (2013). Potential for green microalgae to produce hydrogen, pharmaceuticals and other high value products in a combined process. Crit. Rev. Biotechnol. 33, 172-215. doi: 10.3109/07388551. 2012.681625

Stephens, E., Ross, I. L., King, Z., Mussgnug, J. H., Kruse, O., Posten, C., et al. (2010). An economic and technical evaluation of microalgal biofuels. Nat. Biotechnol. 28, 126-128. doi: 10.1038/nbt0210-126
Sun, X. M., Ren, L. J., Zhao, Q. Y., Ji, X. J., and Huang, H. (2018). Microalgae for the production of lipid and carotenoids: a review with focus on stress regulation and adaptation. Biotechnol. Biofuels 11:272. doi: 10.1186/s13068-0181275-9

Tale, M., Ghosh, S., Kapadnis, B., and Kale, S. (2014). Isolation and characterization of microalgae for biodiesel production from Nisargruna biogas plant effluent. Bioresour. Technol. 169, 328-335. doi: 10.1016/j.biortech.2014. 06.017

White, S., Anandraj, A., and Bux, F. (2011). PAM fluorometry as a tool to assess microalgal nutrient stress and monitor cellular neutral lipids. Bioresour. Technol. 102, 1675-1682. doi: 10.1016/j.biortech.2010.09.097

Wijffels, R. H., and Barbosa, M. J. (2010). An outlook on microalgal biofuels. Science 329, 796-799. doi: 10.1126/science.1189003

Zhao, Y., Li, D., Ding, K., Che, R., Xu, J.-W., Zhao, P., et al. (2016). Production of biomass and lipids by the oleaginous microalgae Monoraphidium sp. QLY1 through heterotrophic cultivation and photo-chemical modulator induction. Bioresour. Technol. 211, 669-676. doi: 10.1016/j.biortech.2016.03.160

Zhao, Y., Li, D., Xu, J. W., Zhao, P., Li, T., Ma, H., et al. (2018). Melatonin enhances lipid production in Monoraphidium sp. QLY-1 under nitrogen deficiency conditions via a multi-level mechanism. Bioresour. Technol. 259, 46-53. doi: 10.1016/j.biortech.2018.03.014

Conflict of Interest: The authors declare that the research was conducted in the absence of any commercial or financial relationships that could be construed as a potential conflict of interest.

Copyright (c) 2020 Singh, Paliwal, Nesamma, Narula and Jutur. This is an open-access article distributed under the terms of the Creative Commons Attribution License (CC BY). The use, distribution or reproduction in other forums is permitted, provided the original author(s) and the copyright owner(s) are credited and that the original publication in this journal is cited, in accordance with accepted academic practice. No use, distribution or reproduction is permitted which does not comply with these terms. 